\title{
Confirmation of species independence and affinity of Musa huangbaioa (Musaceae) - rare endemic banana of China - according to the molecular phylogenetic data
}

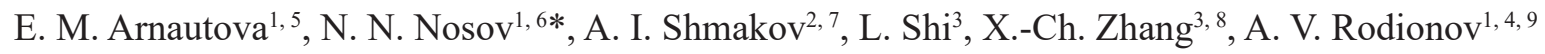 \\ ${ }^{1}$ Komarov Botanical Institute of the Russian Academy of Sciences, Prof. Popova St., 2, St. Petersburg, 199376, Russia \\ ${ }^{2}$ Altai State University, Lenina Pr., 61, Barnaul, Russia \\ ${ }^{3}$ Institute of Botany of Chinese Academy of Sciences, Nanxincun, №.20, Xiangshan, Beijing, China \\ ${ }^{4}$ St.-Petersburg State University, Universitetskaya quay, 7-9, St.-Petersburg, Russia \\ ${ }^{5}$ ORCID iD: https://orcid.org/0000-0003-2859-9820 \\ ${ }^{6}$ E-mail: nnosov2004@mail.ru; ORCID iD: https://orcid.org/0000-0002-7096-9242 \\ ${ }^{7}$ ORCID iD: https://orcid.org/0000-0002-1052-4575 \\ ${ }^{8}$ ORCID iD: https://orcid.org/0000-0003-3425-1011 \\ ${ }^{9}$ ORCID iD: https://orcid.org/0000-0003-1146-1622 \\ * Corresponding author
}

Keywords: China, hybridization, new species, nrITS, $\operatorname{trn} \mathrm{L}-\operatorname{trn} \mathrm{F}$.

Summary. In this article, we research the phylogenetic position of the rare endemic banana, Musa huangbaioa, which was described only in Chinese journal in 1987. This banana was found at the foot of the Mount Emei in Sichuan Province and has remarkable morphological features, e. g., undulated petiole margins, ribbed fruits and irregular form of the seeds, which are rather unusual in the genus and distinguish it from all other species. In addition, due to its uncertain affinity, we researched the position of M. huangbaioa in the Musaceae family with the aid of molecular phylogenetic analysis of two marker sequences, nrITS and $\operatorname{trn} \mathrm{L}-\operatorname{trn} \mathrm{F}$. We found that this species belongs to the large and rather complicated group of Chinese bananas, M. basjoo-M. itinerans clade. According to the ITS data, M. huangbaioa is monophyletic with one M. basjoo specimen that was cultivated in Central America. Probably, this fact represents that this species can be modern hybrid with one of the genomes inherited from M. basjoo s. 1 . The whole group M. basjoo-M. itinerans, which M. huangbaioa belongs to, is well separated within the sect. Musa and could be prone to frequent hybridizations in the natural environment; it requires an additional research for more precise differentiation of the group.

\section{Подтверждение видовой самостоятельности и родства Musa huangbaioa (Musaceae) - редкого эндемичного банана из Китая - по молекулярно-филогенетическим данным}

\author{
Е. М. Арнаутова ${ }^{1}$, Н. Н. Носов ${ }^{1}$, А. И. Шмаков ${ }^{2}$, Л. Шиㅜㄹ, Х.-Ч. Жанг ${ }^{3}$, А. В. Родионов ${ }^{1}$
}

\footnotetext{
${ }^{1}$ Ботанический институт им. В. Л. Комарова РАН, ул. Проф. Попова, 2, г. Санкт-Петербург, 197376, Россия

${ }^{2}$ Алтайский государственный университет, просп. Ленина, 61, г. Барнаул, Россия

${ }^{3}$ Институт Ботаники Китайской Академии Наук, Нанксинчунь, 20, Ксяншан, г. Пекин, Китай
} 
Ключевые слова: гибридизация, Китай, новые виды, $\operatorname{nrTS}, \operatorname{trn} \mathrm{L}-\operatorname{trn} \mathrm{F}$.

Аннотация. В этой статье мы исследуем филогенетическое положение редкого эндемичного банана, Musa huangbaioa, который был описан только в китайском журнале в 1987 г. Этот банан был найден у подножия горы Эмей в провинции Сычуань и имеет примечательные морфологические черты, такие как волнистый край черешка листа, ребристые плоды и неправильную форму семян, которые достаточно необычны для рода и хорошо отделяют этот вид от остальных. Кроме того, из-за его неопределенного родства, мы исследовали положение M. huangbaioa в семействе Musaceae с помощью молекулярно-филогенетического анализа двух маркерных последовательностей, nrITS и $\operatorname{trn} \mathrm{L}-\operatorname{trnF}$. Мы обнаружили, что этот вид принадлежит к большой и достаточно сложной группе китайских бананов, кладе M. basjoo-M. itinerans. По данным ITS, M. huangbaioa монофилетичен с одним образцом M. basjoo, культивировавшимся в Центральной Америке. Возможно, этот факт показывает то, что M. huangbaioa может быть современным гибридом с одним из геномов, унаследованным от M. basjoo s. 1. Вся группа M. basjoo-M. itinerans, к которой принадлежит M. huangbaioa, хорошо отграничена внутри секции Musa и может быть склонна к частым гибридизациям в естественной среде; она требует дополнительного изучения для более точной дифференциации этой группы.

\section{Introduction}

Musaceae is a small paleotropical family which is one of the most important food crops in the world. Its morphological taxonomy is rather well established, nevertheless, there are some difficulties in establishing more precise phylogenetic system basing on molecular genetic data.

As a genus, Musa was established by Linnaeus (1753), but the first infrageneric classification was performed only more than a century later by Sagot (1887). He divided bananas into three groups: giant bananas, fleshy (edible) bananas and ornamental bananas with upright inflorescences and brightly colored bracts. Subsequently, Baker following Sagot's classification formally divided bananas into 3 subgenera: Physocaulis Baker, Eumusa Baker and Rhodochlamys Baker (Baker, 1893). Then Cheesman elevated the first group, giant bananas, to the generic level as the genus Ensete Bruce ex Horan. (Cheesman, 1947). The genus Musa, he divided into four sections basing on morphology and chromosome numbers: Eumusa $(x=11)$, Rhodochlamys $(x=11)$, Australimusa Cheesman $(x=10)$ and Callimusa Cheesman $(x=9,10)$. This classification was widely accepted and used in many treatments of the genus. Later Argent (1976) proposed a new section, Ingentimusa Argent, with the lowest chromosome number, $x=7$. The section is monotypic and distributed only in New Guinea.

New methods of analysis become actual due to the rather morphological unity of the genus (Li et al., 2010). After the development of molecular phylogenetic methods, many phylogenetic schemes basing on molecular data were created. RFLP and AFLP revealed some inconsistencies with the traditional system of the genus Musa, e. g., sect.
Rhodochlamys grouped in the sect. Musa and sect. Australimusa occurred in the sect. Callimusa (Li et al., 2010). In addition, some phylogenetic analyses were performed according to the nuclear and chloroplast gene data. Two main clades were found in the whole genus. The first clade comprised sections Musa and Rhodochlamys and the second species of sections Callimusa, Australimusa and Ingentimusa (Li et al., 2010). Within the whole family genera Musa, Musella (Franch.) H. W. Li and Ensete were monophyletic, but none of the sections previously defined by morphological features. For example, authors suggested the sections Musa and Rhodochlamys combining into the sect. Musa because of the common basic chromosome number, $x=11$, and also some morphological characters ( $\mathrm{Li}$ et al., 2010; Liu et al., 2010). The species from the second clade also have common basic chromosome number $x=7,9,10$. Previous studies revealed that infrageneric classification of bananas is closely correlated with basic chromosome numbers, which lead to the reproductive isolation (Cheeseman, 1947). Of course, new methods of molecular phylogeny will help us clarifying the affinity of the rare and new Musa species.

The genus Musa comprises about 70 species (Simmonds, Weatherup, 1990; De Langhe, 2000; Wu, Kress, 2000; Wong et al., 2002; Häkkinen, Väre, 2008; Häkkinen et al., 2008; Häkkinen, 2009, 2013; Lý et al., 2012). Despite rather knowledge of the genus, some new species have been recently discovered (Lý et al., 2012, Singh, 2014). In 1987 banana sample with clear morphological distinction from the other species was found in China (Zhu, 1987). Its relationships are not very clear. In addition, this species was described only in Chinese local journal and was very little known for the scientists. 
A series of morphological peculiarities of this newly discovered banana and its probable species status raise a question of molecular phylogenetic analysis of this sample and some other bananas from its possible affinity. Although quite a few bananas were studied by different molecular phylogenetic approaches, such analysis can be rather useful in clarifying the relationships of the newly discovered species and especially in possible hybridization cases. Because of the unusual morphological characters of $M$. huangbaioa we took into analysis species from different banana sections and clades. For our analysis we used marker sequences from two genome regions: nuclear (ITS) and chloroplast $(\operatorname{trn} \mathrm{L}-\operatorname{trn} \mathrm{F})$. These sequences are widely applied for phylogenetic reconstruction and species identifying (DNA-barcoding) (Hollingsworth et al., 2011). In bananas, as in other families, the usage of different marker sequences is necessary, because Musa is prone to hybridization in some cases (Swangpol et al., 2007).

\section{Materials and methods}

Plant samples of the studied species were grown from the seeds collected in December 2016 in Sichuan Province in the territory of the Sichuan Academy of Natural Resource Science Emei Mountain Biology Resource Experiment Station and kept in Botanical Garden of Peter the Great, St.-Petersburg, Russia. Other Musa samples were obtained from greenhouses of Komarov Botanical Institute of the RAS (BIN RAS) and collected during the expedition of the Department SaintPetersburg Botanical Garden of Peter the Great to Japan in 2019.

We added other sequences from the international GenBank database https:/www.ncbi.nlm.nih.gov/ nuccore/?term=). All the sequences used for our analysis are presented in the Table. Totally we analyzed 28 ITS and $26 \operatorname{trn} \mathrm{L}-t r n \mathrm{~F}$ sequences using Musella lasiocarpa, a species of closely related genus, as outgroup.

Table

Species marker sequences of the regions ITS1-5.8S rRNA gene-ITS2 and $\operatorname{trn} L-\operatorname{trn} F$ obtained in our research

\begin{tabular}{|c|c|c|c|}
\hline \multirow[b]{2}{*}{ Name of the species } & \multicolumn{2}{|c|}{ Genbank number } & \multirow[b]{2}{*}{ Origin of the sample } \\
\hline & $\begin{array}{c}\text { ITS1-5.8S rRNA } \\
\text { gene-ITS2 }\end{array}$ & $\operatorname{trn} \mathrm{L}-\operatorname{trn} \mathrm{F}$ & \\
\hline Musa acuminata Colla & MW054208 & MW066471 & $\begin{array}{l}\text { Botanical garden of } \\
\text { Peter the Great, St.- } \\
\text { Petersburg, Russia }\end{array}$ \\
\hline Musa acuminata Colla & - & FJ621283.1 & China; Liu et al., 2010 \\
\hline Musa acuminata Colla & FJ428089.1 & - & China; Li et al., 2010 \\
\hline Musa acuminata Colla & KT696474.1 & - & Hapsari et al., 2018 \\
\hline Musa acuminata Colla & KT696473.1 & - & Hapsari et al., 2018 \\
\hline Musa acuminata Colla & KT696472.1 & - & Hapsari et al., 2018 \\
\hline Musa acuminata Colla & KT696471.1 & - & Hapsari et al., 2018 \\
\hline Musa acuminata subsp. truncata (Ridl.) Kiew & - & KU215218.1 & Janssens et al., 2016 \\
\hline Musa balbisiana Colla & KT696445 & - & $\begin{array}{l}\text { Indonesia: Eastern Java; } \\
\text { Hapsari et al., } 2018\end{array}$ \\
\hline Musa balbisiana Colla & - & KU215202.1 & Janssens et al., 2016 \\
\hline Musa banksii F. Muell. & FJ428097.1 & - & Li et al., 2010 \\
\hline Musa banksii F. Muell. & - & KU215211.1 & Janssens et al., 2016 \\
\hline Musa banksii F. Muell. & - & KU215208.1 & Janssens et al., 2016 \\
\hline Musa basjoo Siebold et Zuccarini ex Iinuma & MW054204 & MW066468 & $\begin{array}{l}\text { Botanical Garden of } \\
\text { Peter the Great, St.- } \\
\text { Petersburg, Russia }\end{array}$ \\
\hline Musa basjoo Siebold et Zuccarini ex Iinuma & MW054205 & MW066469 & $\begin{array}{l}\text { Botanical Garden of } \\
\text { Peter the Great, St.- } \\
\text { Petersburg, Russia }\end{array}$ \\
\hline Musa basjoo Siebold et Zuccarini ex Iinuma & MW054206 & - & Garden of Kyoto, Japan \\
\hline Musa basjoo Siebold et Zuccarini ex Iinuma & FJ626374.1 & FJ621270 & China; Liu et al., 2010 \\
\hline Musa basjoo Siebold et Zuccarini ex Iinuma & - & GQ374828 & Gayral et al., 2010 \\
\hline Musa basjoo Siebold et Zuccarini ex Iinuma & KU215073.1 & KU215195.1 & Janssens et al., 2016 \\
\hline
\end{tabular}


Table (end)

\begin{tabular}{|c|c|c|c|}
\hline \multirow[b]{2}{*}{ Name of the species } & \multicolumn{2}{|c|}{ Genbank number } & \multirow[b]{2}{*}{ Origin of the sample } \\
\hline & $\begin{array}{l}\text { ITS1-5.8S rRNA } \\
\text { gene-ITS2 }\end{array}$ & $\operatorname{trn} \mathrm{L}-\operatorname{trn} \mathrm{F}$ & \\
\hline Musa coccinea Andrews & MW054210 & MW066472 & $\begin{array}{l}\text { Botanical Garden of } \\
\text { Peter the Great, St.- } \\
\text { Petersburg, Russia }\end{array}$ \\
\hline Musa coccinea Andrews & FJ428062.1 & - & China; Li et al., 2010 \\
\hline Musa coccinea Andrews & - & KU215200.1 & Janssens et al., 2016 \\
\hline Musa coccinea Andrews & KY214932.1 & - & Iles et al., 2016 \\
\hline Musa exotica R. V. Valmayor & FJ428063.1 & FJ428198 & Li et al., 2010 \\
\hline Musa huangbaioa Z. Y. Zhu & MW054207 & MW066470 & $\begin{array}{l}\text { Botanical Garden of } \\
\text { Peter the Great, St.- } \\
\text { Petersburg, Russia }\end{array}$ \\
\hline Musa itinerans Cheesman & FJ428098.1 & - & Li et al., 2010 \\
\hline Musa jackeyi W. Hill & HQ331362 & - & Hřibová et al., 2010 \\
\hline Musa jackeyi W. Hill & & KU215203.1 & Janssens et al., 2016 \\
\hline Musa lolodensis Cheesman & KU215094 & KU215213.1 & Janssens et al., 2016 \\
\hline Musa maclayi F. Muell. & FJ428068 & - & Li et al., 2010 \\
\hline Musa maclayi F. Muell. & HQ331373 & - & Hřibová et al., 2011 \\
\hline Musa maclayi var. namatani Argent & - & KU215212.1 & Janssens et al., 2016 \\
\hline Musa maclayi F. Muell. & - & KU215216.1 & Janssens et al., 2016 \\
\hline Musa mannii $\mathrm{H}$. Wendl. ex Baker & - & FJ621278.1 & Liu et al., 2010 \\
\hline Musa ornata Roxb. & FJ428096.1 & - & Li et al., 2010 \\
\hline Musa ornata Roxb. & - & FJ621278 & Liu et al., 2010 \\
\hline $\begin{array}{l}\text { Musa peekelii subsp. angustigemma (N. W. } \\
\text { Simmonds) Argent }\end{array}$ & - & KU215209.1 & Janssens et al., 2016 \\
\hline Musa rubinea Häkkinen et C. H. Teo & FJ428093.1 & FJ428163 & Li et al., 2010 \\
\hline Musa schizocarpa N. W. Simmonds & FJ428088.1 & - & Li et al., 2010 \\
\hline Musa schizocarpa N. W. Simmonds & HQ331332.1 & - & Hřibová et al., 2010 \\
\hline Musa schizocarpa N. W. Simmonds & & KU215204.1 & Janssens et al., 2016 \\
\hline Musa schizocarpa N. W. Simmonds & & KU2152210.1 & Janssens et al., 2016 \\
\hline Musa textilis Née & MW054211 & - & Garden of Kyoto, Japan \\
\hline Musa textilis Née & FR727896.1 & - & Hřibová et al., 2011 \\
\hline Musa textilis Née & & KU215214.1 & Janssens et al., 2016 \\
\hline $\begin{array}{l}\text { Musa tonkinensis R. V. Valmayor, L. D. Danh } \\
\text { et Häkkinen }\end{array}$ & FJ428099.1 & FJ428178 & China; Li et al., 2010 \\
\hline Musa velutina $\mathrm{H}$. Wendl. et Drude & MW054209 & - & $\begin{array}{l}\text { Botanical Garden of } \\
\text { Peter the Great, St.- } \\
\text { Petersburg, Russia }\end{array}$ \\
\hline Musa velutina $\mathrm{H}$. Wendl. et Drude & FJ428092.1 & - & Li et al., 2010 \\
\hline Musa velutina $\mathrm{H}$. Wendl. et Drude & KJ847168.1 & - & Ning et al., 2014 \\
\hline Musa violascens Ridl. & FJ428071 & & Li et al., 2010 \\
\hline Musa violascens Ridl. & - & KU215.217.1 & Janssens et al., 2016 \\
\hline Musa yunnanensis Häkkinen et $\mathrm{H}$. Wang & FJ428095.1 & & Li et al., 2010 \\
\hline Musa yunnanensis Häkkinen et $\mathrm{H}$. Wang & - & KT257599 & $\begin{array}{l}\text { Thailand; Somana et al., } \\
2015\end{array}$ \\
\hline Musella lasiocarpa (Franch.) H. W. Li & AY673072 & - & Prince, Kress, 2004 \\
\hline Musella lasiocarpa (Franch.) H. W. Li & - & KT257602 & $\begin{array}{l}\text { Thailand; Somana et al., } \\
2015\end{array}$ \\
\hline
\end{tabular}

Genomic DNA from the leaf material was extracted using Qiagen DNeasy Plant Mini Kit according to the product manual. The ITS1-5.8S
rRNA gene-ITS2 was amplified with primers ITS 1P (Ridgway et al., 2003) and ITS 4 (White et al., 1990). Amplification parameters for this region were: one 
cycle of $95^{\circ} \mathrm{C}$ for 5 min., 35 cycles: $95^{\circ} \mathrm{C}$ for 40 s., $52-56{ }^{\circ} \mathrm{C}$ for 40 s., $72{ }^{\circ} \mathrm{C}$ for 40 s., final elongation $72{ }^{\circ} \mathrm{C}$ for $10 \mathrm{~min}$. Marker region of chloroplast genome, including $\operatorname{trn} \mathrm{L}$ gene, $\operatorname{trn} \mathrm{L}$ intron and $\operatorname{trn} \mathrm{L}-$ $\operatorname{trn} \mathrm{F}$ intergenic spacer was amplified with primers tabC and tabF (Taberlet et al., 1991), according to the following program: one cycle of $95{ }^{\circ} \mathrm{C}$ for 5 min., 35 cycles: $95{ }^{\circ} \mathrm{C}$ for 1 min., $52-56{ }^{\circ} \mathrm{C}$ for 1 min. 10 s., $72{ }^{\circ} \mathrm{C}$ for $1 \mathrm{~min} .10 \mathrm{~s}$., final elongation $72{ }^{\circ} \mathrm{C}$ for $10 \mathrm{~min}$. Trn $\mathrm{L}-\operatorname{trn} \mathrm{F}$ region was sequenced using the primer set (forward-reverse): tabC-tabD and tabE-tabF. All sequencing was performed on the sequencer ABI PRIZM 3100 sequencer at the Center of Collective Usage (CUS) BIN RAS with a BigDyeTM Terminator Kit ver. 3.1 set of reagents. Then, chromatograms were analyzed with the aid of Chromas Lite ver. 2.01. Alignment of the sequences was done by Muscle algorithm (Edgar, 2004) included in MEGA ver. 7.0 (Kumar et al., 2016) and adjusted manually.

Molecular phylogenetic analysis was performed by the Bayesian method and Maximum Likelihood. Models for phylogenetic tree estimation were selected using Akaike Information Criterium (AIC) with MEGA 7.0 (Kumar et al., 2016) and jModelTest 2.1.6 (Darriba et al., 2012). Unambiguous indels were coded with SeqState 1.4.1 (Müller, 2005) and then used in Bayesian analysis as binary characters ("restriction" option). We used Musella lasiocarpa (Franch.) H.W. Li as outgroup, because according to the previous research it occupies rather distant position in the family Musaceae (Simmonds, 1962; Li et al., 2010). Bayesian analysis was carried out with 1-1.5 million generations until the standard deviation of split frequencies was lower than 0.01 . The first $25 \%$ of trees were discarded, option "burnin". Maximum Likelihood analysis was conducted by MEGA 7.0; 1000 bootstrap replications. In the resulting trees, posterior probability is shown at the nodes as the first value, bootstrap value as the second. Clades with $100-90 \%$ of posterior probability and bootstrap index we consider as strongly supported, $89-70 \%$ - as moderately supported and 50-69 \% as weakly supported. Indexes below $50 \%$ we regard as no support for the clade.

\section{Taxonomic treatment}

M. huangbaioa is an endemic plant growing in subtropical conditions of China. We studied specimen growing in culture at Sichuan Academy of Natural Resource Science Emei Mountain Biology Resource Experiment Station. This species was described by Z. Y. Zhu in Chinese local journal, and thus was forgotten for the majority of researchers. Here we need to remind of its existence and to provide a correct link to the description of this species.

Musa huangbaioa Z. Y. Zhu, 1987, in Chuan Yao Xiao Kan 1(9): 41.

Holotype: [China] "25 IX 1983. Z. Y. Zhu 1278 Typus Sichnan [Sichuan] School of Chinese Materia Medica); Emei Shan, alt. 470 m. Z. Y. Zhu 2341 (species sativa)". Holotype in EMA.

Etymology. Probably from the Chinese name of Amur corktree, Huang Bai, or from the Chinese word that means "cork".

Distribution and habitat. Grows at the foot of the Emei Mount, Sichuan Province, ca. $470 \mathrm{~m}$ alt., cultivated. The original specimen is cultivated in the Botanical Garden of the experimental station in Beijing. The seeds of $M$. huangbaioa were brought to the Botanical Garden of Peter the Great, St.Petersburg, Russia, and now this banana successfully flowers and propagates.

The plant appearance and some morphological features are presented in Fig. 1.

\section{Results}

Musa huangbaioa, a rare endemic banana, forms a clade with various $M$. basjoo Siebold et Zuccarini ex Iinuma samples according to the nuclear and chloroplast datasets ( $\mathrm{PP}=99 \%, \mathrm{BS}=98 \%$ - ITS data, $\mathrm{PP}=87$, BS unsupported - trnL-trnF) (Fig. 2, 9). It falls into the Clade I that was defined by previous analyses (see $\mathrm{Li}$ et al., 2010; Liu et al., 2010; Feng et al., 2016). This species with M. basjoo forms a separate subclade in the Clade I representing the section Musa. It is notable that M. huangbaioa has the same ITS sequences as one sample of M. basjoo cultivated in Mexica (Fig. 2).

According to the ITS data (PP $=99 \%, \mathrm{BS}=$ $98 \%$ ), the sister subclade in the Clade I corresponds to the sections Musa and Rhodochlamys (Fig. 2). M. banksii F. Muell occupies an uncertain position in this subclade. The sect. Rhodochlamys forms a highly supported group $(\mathrm{PP}=100 \%, \mathrm{BS}=88 \%$ ) within this subclade; $M$. rubinea Häkkinen et C. H. Teo is sister to the samples of M. velutina $\mathrm{H}$. Wendl. et Drude by ITS data (Fig. 2). ITS sequences of $M$. yunnanensis Häkkinen et $\mathrm{H}$. Wang (sect. Musa) are related to M. ornata Roxb. (sect. Rhodochlamys) and M. balbisiana Colla (sect. Musa) has a sister 
position to all other species in the Clade I according to the ITS analysis. Chloroplast $t r n \mathrm{~L}-\operatorname{trn} \mathrm{F}$ sequences show slightly other picture (Fig. 3). The second subclade of the sections Musa and Rhodochlamys is present as well ( $\mathrm{PP}=98 \%$, BS unsupported) but M. acuminata forms a polytomy rather than any of the monophyletic groups (Fig. 3).

As in previous studies ( $\mathrm{Li}$ et al., 2010; Liu et al., 2010; Feng et al., 2016), Clade II comprises species of the sections Australimusa and Callimusa $(\mathrm{x}=9,10)$. It is well supported according to the ITS dataset $(\mathrm{PP}=100 \%, \mathrm{BS}=98 \%$, Fig. 2 ) but has weak support basing on $\operatorname{trn} \mathrm{L}-\operatorname{trn} \mathrm{F}$ analysis $(\mathrm{PP}=$
$60 \%$, BS $=62 \%$, Fig. 3). ITS sequences of the $M$. coccinea Andrews sample cultivated in greenhouses of BIN RAS (St.-Petersburg) were identical with the sequences from GenBank database. This species is monophyletic with M. exotica R.V.Valmayor ( $\mathrm{PP}=94 \%, \mathrm{BS}=91 \%$ ) by ITS data but takes an isolated position according to the $t r n \mathrm{~L}-t r n \mathrm{~F}$ sequences whereas $M$. exotica forms a strongly supported clade with $M$. violascens Ridl. $(\mathrm{PP}=99 \%)$. M. violascens (sect. Callimusa) is a sister to the subclade that contains sect. Australimusa $(\mathrm{PP}=100 \%, \mathrm{BS}=98 \%)$ in ITS dataset.
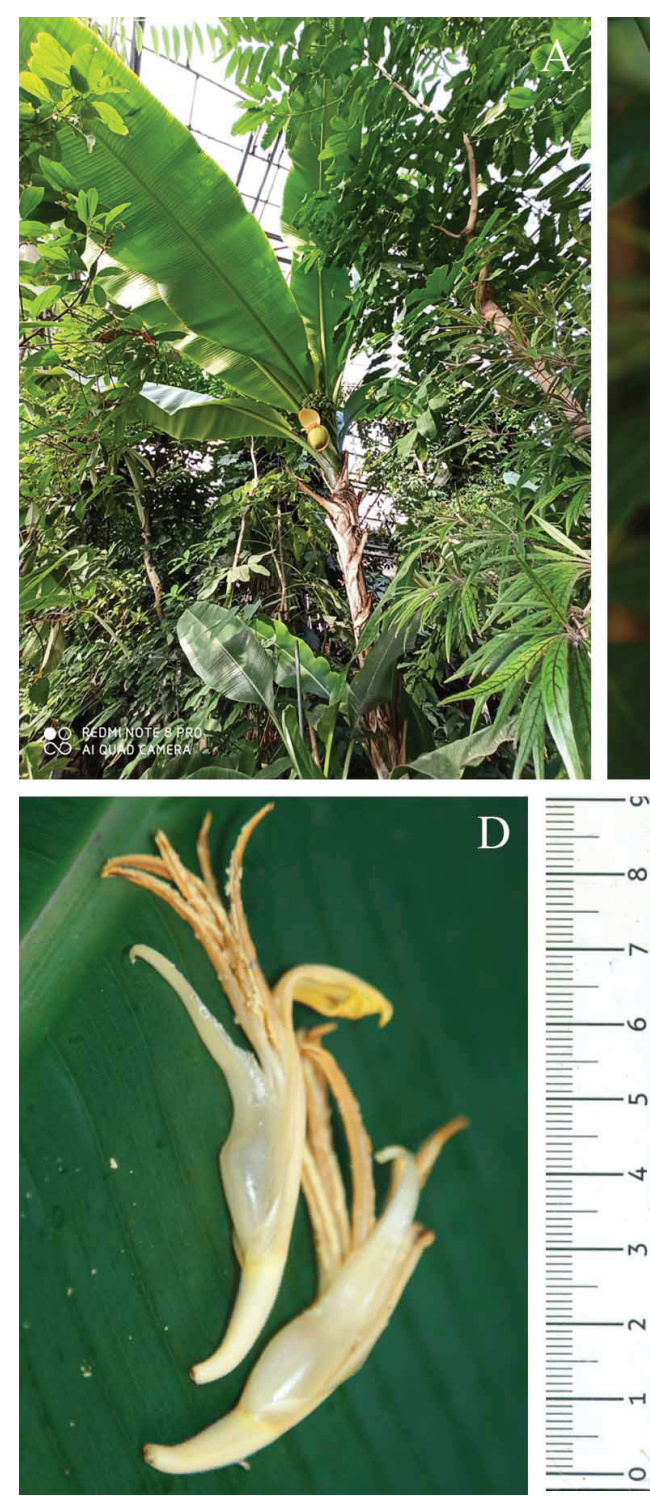
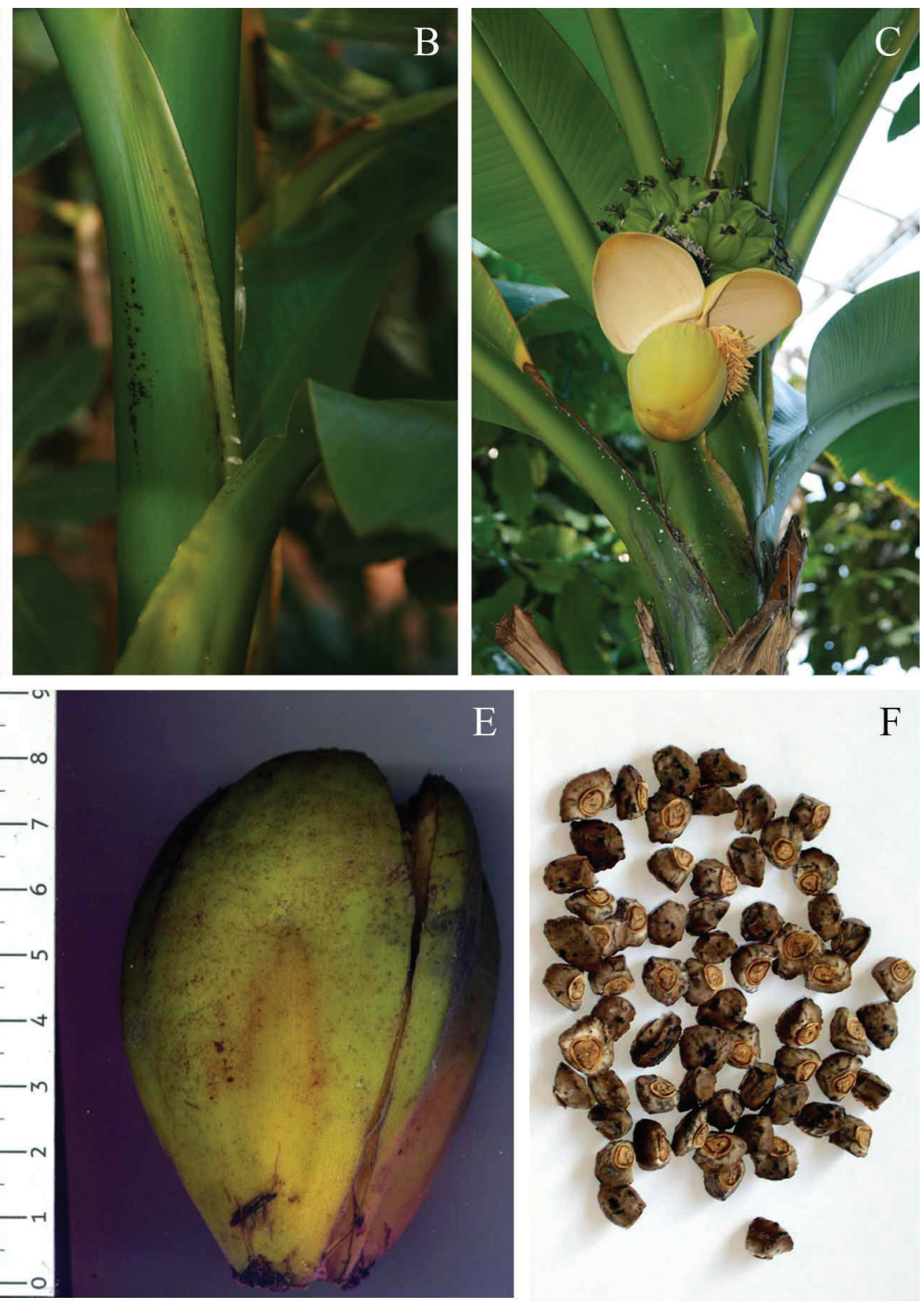

Fig. 1. Musa huangbaioa in the greenhouses of the Botanical Garden of Peter the Great, St.-Petersburg and its characteristic features: A - Leaves and inflorescence of Musa huangbaioa, St.-Petersburg; B - Leaf sheaths and part of the pseudostem; C - Inflorescence of Musa huangbaioa; D - Male flowers of Musa huangbaioa; E - Musa huangbaioa, ripe fruit; F - Musa huangbaioa, seeds. 


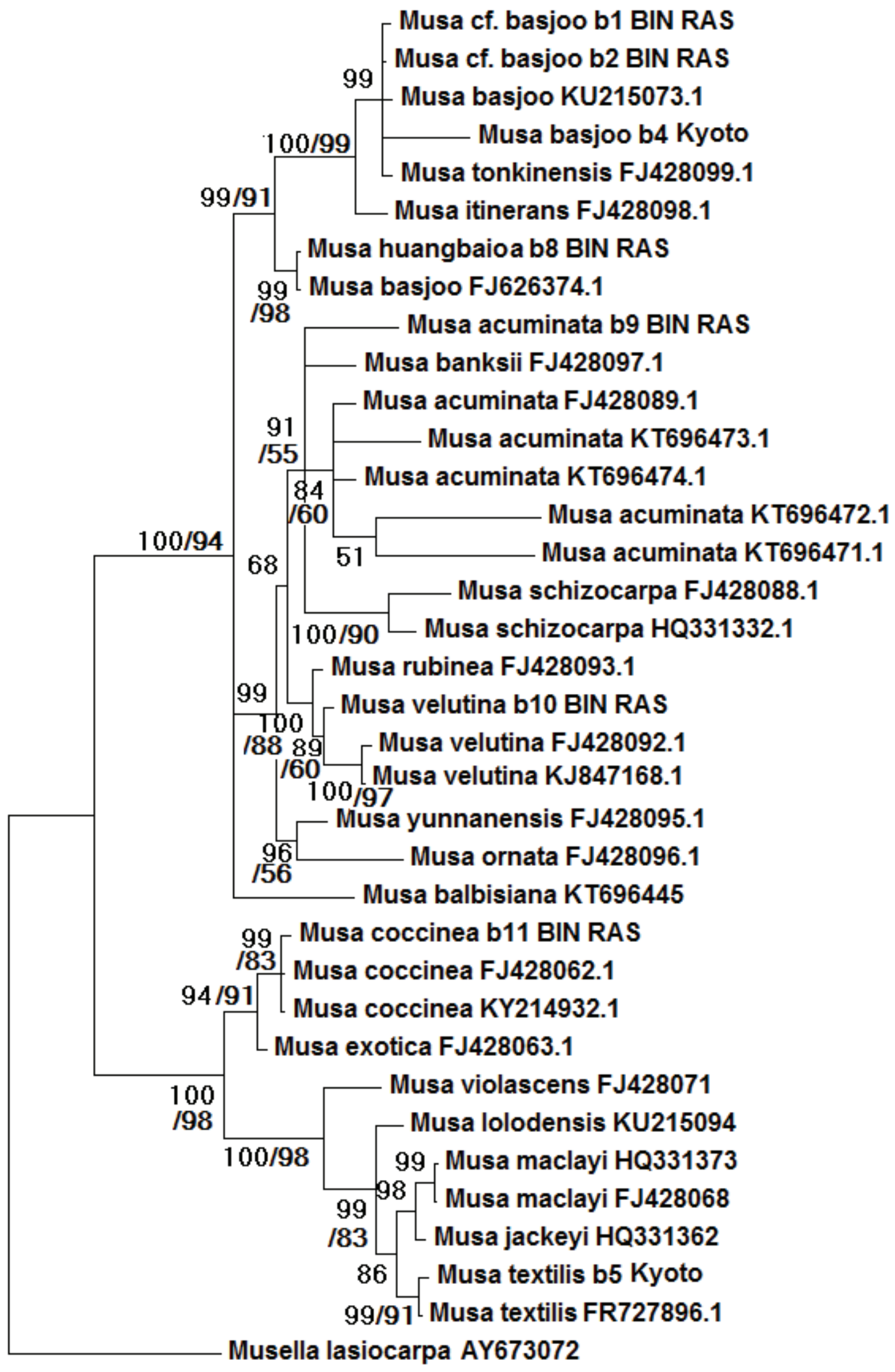




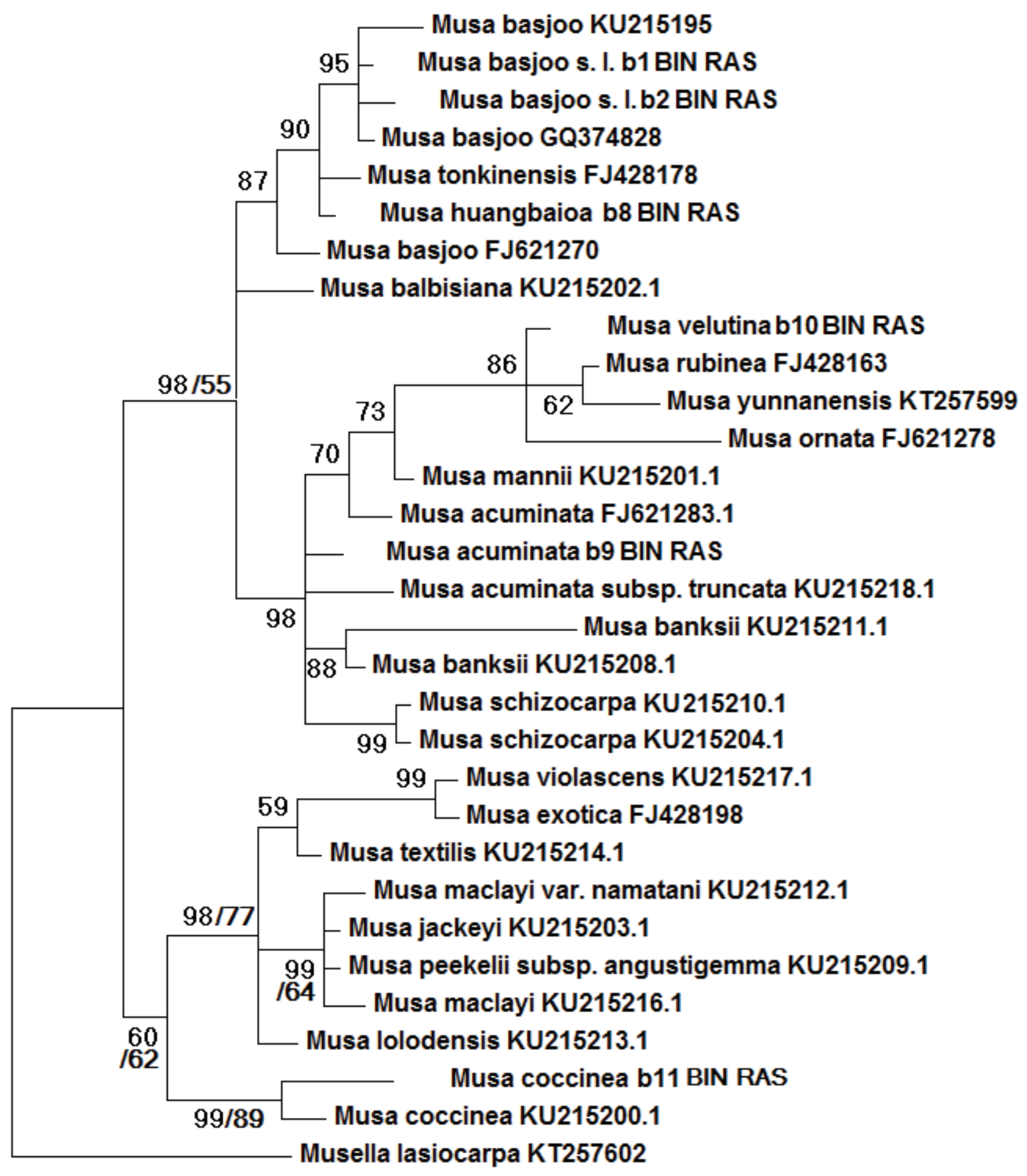

Fig. 3. Phylogenetic placement of Musa huangbaioa in the genus Musa according to the analysis of $\operatorname{trn} \mathrm{L}-\operatorname{trn} \mathrm{F}$ sequence data; BI posterior probability is shown the first, ML bootstrap index - the second.

\section{Discussion}

Species of the most part of banana family (Musaceae) mainly have wide natural range, but M. huangbaioa is described from the foot of Emei mountain and thus is narrow endemic. This is rather unusual feature for the bananas. The morphological characters of Musa huangbaioa show that it belongs to the sect. Musa: its pseudostems are tall, bracts are yellow and sometimes brownish, leaves are with glaucous tinge. This species also differs from all other banana species by unusual ribbed shape of the fruits and undulated petiole margins. The floral characters of $M$. huangbaioa, as well as the plant height, mostly resemble $M$. itinerans. Seeds also resemble that of the sect. Musa; they are angular, 
more or less tetrahedral. According to the ITS and $\operatorname{trn} \mathrm{L}-t r n \mathrm{~F}$ data, this species is closely related to M. basjoo. It is taller than M. basjoo, its height is almost like that of M. acuminata. The floral characters resemble $M$. itinerans Cheesman, but the stipule is longer than in M. itinerans. Moreover, according to the ITS data, $M$. huangbaioa is identical to the sample of M. basjoo cultivated in Central America and has the same $\operatorname{trn} \mathrm{L}-\operatorname{trn} \mathrm{F}$ sequences as M. basjoo. Speaking of this group as a whole, Chinese group of $M$. basjoo and M. itinerans is rather uniform and well separated within the sect. Musa (see Simmonds, 1962; Simmonds, Weatherup, 1990; Li et al., 2010). It could originate in Oligocene (Christelová et al., 2011) and, according to the morphological data, form after the separation of M. balbisiana, M. acuminata and M. schizocarpa lineages (Simmonds, 1962). As shown in our previous article, M. basjoo affinity contains complex hybrid species, probably, with the different maternal genomes. We can assume that this banana, M. huangbaioa, can be modern hybrid with the maternal genome inherited from M. basjoo. Unusual fruit shape can be adaptation to the mountain conditions.

According to our data, Musa sect. Rhodochlamys is nested with the sect. Musa in the clade that also comprises $M$. acuminata affinity group. This well corresponds with the hypothesis by N. Simmonds (1962), that M. acuminata "stock" could be ancestral for the whole section Rhodochlamys. Nevertheless, we do not combine this section with the section Musa due to morphological distinction between these sections. Bananas, as well as many other flowering plants, are subject of reticulate evolution and, thus, their natural system can be the network rather than dichotomous picture. This may really complicate their taxonomy.

The second clade that contains sections Callimusa and Australimusa also presents the reticulation evidence. Musa exotica from the sect. Callimusa, which is rather morphologically distinct from the other species of the sections Callimusa and Australimusa in seed characters (Li et al., 2010), falls into the clade with its relatives with similar seeds, M. coccinea. This fits well with the previous studies (Li et al., 2010; Liu et al., 2010; Christelová et al., 2011; Feng et al., 2016). But maternal genome of $M$. exotica, as it appears, is related to another species of the sect. Callimusa, M. violascens. M. exoti$c a$ can be the introgressant that originated from the hybridization between members of two clades/lines from the sect. Callimusa retaining the seed traits of M. coccinea group. As in previous cases, this possible hybrid species retains the initial chromosome number of the section, $2 n=20$. We can assume that bananas in natural conditions form homoploid hybrids without chromosome number duplication (Feliner et al., 2017).

\section{Conclusions}

Molecular phylogenetic methods allowed us to establish the clear relationship of the rare endemic banana species, Musa huangbaioa, which has peculiar and unusual morphological features. $M$. huangbaioa appeared to be related to the separate Chinese banana group, M. basjoo-M. itinerans affinity; this placement was supported by the seed shape of $M$. huangbaioa along with the color and shape of male bracts and male flowers. At the same time, our studies showed interesting events of the possible reticulation within this group. This new species, M. huangbaioa, can be hybridogenous and, possibly, its morphological characters formed because of the gene combination. We also confirmed convenience and suitability of the marker sequences from the different genomes, $\operatorname{nrITS}$ and $\operatorname{trn} \mathrm{L}-\operatorname{trn} \mathrm{F}$ for the identification of affinity in plants, "molecular barcoding" (see Hollingsworth et al., 2011).

\section{Acknowledgements}

Authors are very grateful to E. A. Lebedev and all employees of Botanical Garden of Peter the Great for the excellent condition of all collections, to the late Yu. N. Karpun, Dr. Sc., Head of the Subtropical Botanical Garden of Kuban for kindly provided seeds of this species to our Institute, and to all employees of the Kyoto and Tsukuba Botanical Gardens (Japan) for the samples provided.

The work was done on a state task of the Peter the Great Botanical Garden department of BIN RAS "Collections of the living plants of Komarov Botanical Institute of the RAS (history, modern state, perspectives of development and usage)" № AAAA-A18-118032890141 - 4, state task of A1tai State University № FZMW-2020-003, and with the support of the RFBR grant № 18-18-04-01040 and partially S-Pb SU grant ID 60256916. Our research was done using equipment of The Core Facilities Center "Cell and Molecular Technologies in Plant Science" at the Komarov Botanical Institute of the RAS (St.-Petersburg, Russia). 


\section{REFERENCES}

Argent G. C. G. 1976. The wild bananas of Papua New Guinea. Notes from the Royal Botanic Garden, Edinburgh 35: 77-114.

Baker J. G. 1893. A synopsis of the genera and species of Musaceae. Ann. Bot. (Oxford) 7: 189-229.

Cheesman E. E. 1947. Classification of the bananas. I. The genus Ensete Horan. and the genus Musa L. Kew Bull. 2(2): 97-117. DOI: 10.2307/4109207

Christelová P., Valárik M., Hřibová E., Langhe E. De, Doležel J. 2011. A multi gene sequence-based phylogeny of the Musaceae (banana) family. BMC Evolutionary Biology 11: 103. DOI: 10.1186/1471-2148-11-103

Darriba D., Taboada G. L., Doallo R., Posada D. 2012. jModelTest 2: more models, new heuristics and parallel computing. Nature Methods 9(8): 772. DOI: 10.1038/nmeth.2109

De Langhe E. 2000. Diversity in the genus Musa: its significance and its potential. Acta Hort. 540: 81-88. DOI: 10.17660/ActaHortic.2000.540.9

Edgar R. C. 2004. MUSCLE: multiple sequence alignment with high accuracy and high throughput. Nuc. Ac. Res. 32: 1792-1797. DOI: 10.1093/nar/gkh340

Feliner G. N., Álvarez I., Fuertes-Aguilar J., Heuertz M., Marques I., Moharrek F., Piñeiro R., Riina R., Rosselló J. A., Soltis P. S., Villa-Machío I. 2017. Is homoploid hybrid speciation that rare? An empiricist's view. Heredity 118: 513-516. DOI: 10.1038/hdy.2017.7

Feng H., Chen Y., Li B., Wu Y. 2016. Molecular phylogeny of genus Musa determined by simple sequence repeat markers. Plant Genetic Resources: Characterization and Utilization 14(3): 192-199. DOI: 10.1017/ S1479262115000222

Häkkinen M. 2009. Musa chunii Häkkinen, a new species (Musaceae) from Yunnan, China and taxonomic identity of Musa rubra. J. Syst. Evol. 47 (1): 87-91. DOI: 10.1111/j.1759-6831.2009.00005.x

Häkkinen M. 2013. Reappraisal of sectional taxonomy in Musa (Musaceae). Taxon 62: 809-813. DOI: $10.12705 / 624.3$

Häkkinen M., Hong W., Ge X.-J. 2008. Musa itinerans (Musaceae) and its Intraspecific taxa in China. Novon 18: 50-60. DOI: $10.3417 / 2006162$

Häkkinen M., Väre H. 2008. Typification and check-list of Musa L. names (Musaceae) with nomenclatural notes. Adansonia, ser. 3 30(1): 63-112. DOI: 10.5252/a2009n1a3

Hollingsworth P. M., Graham S. W., Little D. P. 2011. Choosing and using a plant DNA barcode. PLoS ONE 6(5): e19254. DOI: 10.1371/journal.pone.0019254

Kumar S., Stecher G., Tamura K. 2016. MEGA7: Molecular Evolutionary Genetics Analysis version 7.0 for Bigger Datasets. Mol. Biol. Evol. 33(7): 1870-1874. DOI: 10.1093/molbev/msw054

Li L.-F, Häkkinen M., Yuan Y.-M., Hao G., Ge X.-J. 2010. Molecular phylogeny and systematics of the banana family (Musaceae) inferred from multiple nuclear and chloroplast DNA fragments, with a special reference to the genus Musa. Mol. Phyl. Evol. 57: 1-10. DOI: 10.1016/j.ympev.2010.06.021

Linnaeus $C$. 1753. Species plantarum, exhibentes plantas rite cognitas, ad genera relatas, cum differentiis specificis, nominibus trivialibus, synonymis selectis, locis natalibus, secundum systema sexuale digestas. Vol. I. Holmiae: L. Salvius. 560 pp. DOI: 10.5962/bhl.title.669

Liu A.-Z., Kress W. J., Li D.-Z. 2010. Phylogenetic analyses of the banana family (Musaceae) based on nuclear ribosomal (ITS) and chloroplast (trnL-F) evidence. Taxon 59(1): 20-28. DOI: 10.1002/TAX.591003

Lý N.-S., Lê C.-K., Trieu T.-D., Haevermans A., Lowry II P. P., Haevermans T. 2012. A distinctive new species of wild banana (Musa, Musaceae) from northern Vietnam. Phytotaxa 75: 33-42. DOI: 10.11646/phytotaxa.75.1.3

Müller K. 2005. SeqState - primer design and sequence statistics for phylogenetic DNA data sets. Applied Bioinformatics 4: 65-69. DOI: 10.2165/00822942-200504010-00008

Ridgway K. P., Duck J. M, Young J. P. W. 2003. Identification of roots from grass swards using PCR-RFLP and FFLP of the plastid trnL (UAA) intron. BMC Ecol. 3: 8. DOI: 10.1186/1472-6785-3-8

Sagot P. 1887. Sur le genre bananier. Bulletin de la Société botanique de France 34: 328-330.

Simmonds N. W. 1962. The evolution of bananas. London: Longmans. $170 \mathrm{pp}$.

Simmonds N. W., Weatherup S. T. C. 1990. Numerical taxonomy of the wild bananas (Musa). New Phytol. 115: 567-571. DOI: 10.1111/j.1469-8137.1990.tb00485.x

Singh L. J. 2014. Musa indandamanensis L. J. Singh: A new species (Musaceae) from the Bay Islands, India. Taiwania 59(1): 26-36. DOI: 10.6165/tai.2014.59.26

Swangpol S., Volkaert H. A., Sotto R. C., Seelanan T. 2007. Utility of selected non-coding chloroplast DNA sequences for lineage assessment of Musa interspecific hybrids. J. Biochem. Molec. Biol. 40: 577-587. DOI: 10.5483/ bmbrep.2007.40.4.577

Taberlet P., Gielly L., Pautou G., Bouve J. 1991. Universal primers for amplification of three 430 non-coding regions 431 of chloroplast DNA. Pl. Mol. Biol. 17: 1105-1109. DOI: 10.1007/BF00037152 
White T. J., Bruns T., Lee S., Taylor J. 1990. Amplification and direct sequencing of fungal ribosomal RNA genes for phylogenetics. In: PCR Protocols: a Guide to Methods and Applications. Eds. M. A. Innis, D. H. Gelfand, J. J. Sninsky, T. J. White. San Diego: Academic Press. Pp. 315-322. DOI: 10.1016/b978-0-12-372180-8.50042-1

Wong C., Kiew R., Argent G. C. G., Set O., Lee S. K., Gan Y. Y. 2002. Assessment of the validity of the sections in Musa (Musaceae) using AFLP. Ann. Bot. 90: 231-238. DOI: 10.1093/aob/mcf170

Wu D-L., Kress W. J. 2000. Musaceae. In: Flora of China. Vol. 24. Pp. 297-313. URL: http://www.efloras.org/ florataxon.aspx?flora_id=2\&taxon_id=10588

Zhu Z. Y. 2007. Musaceae. In: Plants of Mount Emei. L. Zhen-Yu, S. Lei (eds). Beijing: Beijing Science and Technology Publishing House. 792 pp. 